\title{
環境カドミウム曝露の健康影響に関する縦断的研究
}

\author{
有 澤 孝 吉 \\ 長崎大学医学部衛生学教室
}

\section{Longitudinal Studies on the Health Effects of Exposure to Environmental Cadmium}

\author{
Kokichi ARISAWA \\ Department of Preventive Medicine and Health Promotion, Nagasaki University School of Medicine, Nagasaki
}

\begin{abstract}
Renal damage induced by cadmium (Cd) results in a proximal renal tubular dysfunction, characterized by low-molecular weight (LMW) proteinuria, renal glucosuria, generalized aminoaciduria and decreased renal tubular reabsorption of uric acid and phosphate. Since LMW proteinuria is thought to be one of the earliest adverse health effects caused by Cd, the prevention of the progress of LMW proteinuria is important to avoid further deteriorations in the health condition. Follow-up studies on residents in Cd-polluted areas and Cd-exposed workers have indicated that Cd-induced LMW proteinuria is generally irreversible and progressive even after the cessation or reduction of exposure. The intensity of exposure and the body burden of $\mathrm{Cd}$ before the reduction of exposure may influence the prognosis of $\mathrm{Cd}$-induced LMW proteinuria. Several studies have reported a gradual decline in the glomerular filtration rate even after the reduction of $\mathrm{Cd}$ exposure.

Cohort studies performed in Cd-polluted areas of Japan showed that renal tubular dysfunction and a decreased glomerular filtration rate were strongly associated with increased risk of mortality. However, the results also suggested that overall mortality rates in $\mathrm{Cd}$-polluted areas were not necessarily increased, because of the low mortality among those with urinary $\beta_{2}$-microglobulin concentrations $<1,000 \mu \mathrm{g} / \mathrm{g}$ creatinine. At present, incidence data are too limited to draw a conclusion regarding the cancer risk among residents in Cd-polluted areas.
\end{abstract}

Key words: $\beta_{2}$-microglobulin（ $\beta_{2}$-マイクログロブリン), cadmium（カドミウム）, cancer incidence（がん罹患率）， cohort study（コホート研究）, kidney function (腎機能), mortality（死亡率）

緒言

慢性カドミウム $(\mathrm{Cd})$ 中毒における標的藏器は腎臟で あり，Cdによる腎障害が，低分子量蛋白尿，腎性糖尿， 全般性アミノ酸尿, 尿細管における尿酸およびリン酸の 再吸収率の低下などを主徵とする近位尿細管障害であ ることは, Friberg らの Cd 蓄電池工場労働者についての 報告 $(1950)^{1)}$ をはじめ, 多くの研究により確立されてい る2)。わが国では, 富山県神通川流域でイタイイタイ病 が発生したために, Cd の骨への影響が特に注目され,

受付 2001 年 1 月 18 日, 受理 2001 年 2 月 27 日

Reprint requests to: Kokichi ARISAWA

Department of Preventive Medicine and Health Promotion, Nagasaki University School of Medicine, 1-12-4 Sakamoto, Nagasaki 8528523, Japan
「イタイイタイ病および慢性カドミウム中毒に関する総 合的研究」研究班などによって長年研究が行われてき た。しかし，イタイイタイ病は， Cdによる健康影響のい わば水山の頂点に過ぎず，全国各地の Cd 污染地域には， $\mathrm{Cd}$ による腎尿細管障害を持つ人が数多く存在する。 $\beta_{2}-$ microglobulin $\left(\beta_{2}-\mathrm{MG}\right)$, retinol-binding protein $(\mathrm{RBP})$ な どの低分子量血漿蛋白の尿中排泄増加（低分子量蛋白尿 または尿細管性蛋白尿) は, Cdによる健康影響のうちで 最も早期に出現するものの一つであることから，低分子 量蛋白尿の進展を防ぐことは, より重度の健康障害を予 防する上で重要であると考えられている ${ }^{3)}$ 。これまで, $\mathrm{Cd}$ 作業者や Cd 污染地域住民において, 曝露が軽減した 後に低分子量蛋白尿が回復するのか, あるいは回復せず に悪化していくのかどうかについて関心が持たれてき た。 
また，日本の Cd 污染地域を中心として， Cd 曝露およ び Cd による低分子量蛋白尿・腎尿細管障害と死亡率と の関連が議論の的となってきた。本総説では, $\mathrm{Cd}$ 曝露軽 减後の低分子量蛋白尿・腎尿細管障害の予後, および $\mathrm{Cd}$ 污染地域住民の死亡率についての縦断的研究を中心に, 著者らの調査結果を含めて概説する。

\section{1. $\mathrm{Cd}$ 曝露軽減後の低分子量蛋白尿・腎尿細管障害の予 後 (可逆性)}

$\mathrm{Cd}$ 曝露軽減後の腎尿細管障害の予後（可逆性）につい ての初期の研究は, 尿中蛋白の定性検査や尿中総蛋白濃 度などを腎障害の指標として用いていた。この中には， Cdによる蛋白尿は可逆的であるとした Tsuchiya の研究 ${ }^{4)}$
も含まれているが，尿中総蛋白は，Cdによる腎尿細管障 害の指標としては感度・特異度の点で限界がある。これ

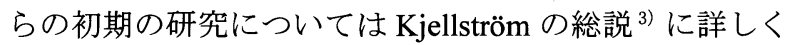
まとめられているので，本稿では，それ以後の尿中低分 子量蛋白の定量を用いた研究を中心に, $\mathrm{Cd}$ 曝露労働者の 調査結果も含めて述べる。

Table 1 に，主な研究について，年代順に対象集団，追 跡期間, 腎機能の変化, 曝露状況, 血液中 $\mathrm{Cd}$ 濃度およ び尿中 $\mathrm{Cd}$ 濃度の変化をまとめて示した。低分子量蛋白 尿の診断のための尿中 $\beta_{2}-\mathrm{MG}$ 濃度のカットオフポイン トは報告によって異なっていたので（欧米では $300 \mu \mathrm{g} / \mathrm{g}$ creatinine [cr.] が, 日本では $1,000 \mu \mathrm{g} / \mathrm{g}$ cr. が用いられるこ とが多い)，ここでは論文中で用いられているものをそ

Table 1 Follow-up studies on the prognosis of cadmium-induced low-molecular weight proteinuria after the reduction of exposure

\begin{tabular}{|c|c|c|c|}
\hline Author (year) & $\begin{array}{l}\text { Population, Country } \\
\text { (Years of follow-up) }\end{array}$ & Change in renal function & Change in exposure, B-Cd and U-Cd \\
\hline Roels et al. $(1982)^{5)}$ & $\begin{array}{l}11 \text { Cd workers, } \\
\text { Belgium } \\
3.6 \text { years }\end{array}$ & $\mathrm{U}-\beta_{2} \mathrm{M} 570 \rightarrow 2,820 \mu \mathrm{g} / \mathrm{g}$ cr. & $\begin{array}{l}\text { Removal from occupational exposure } \\
\text { B-Cd } 31.9 \rightarrow 13.1 \mu \mathrm{g} / 1 \\
\mathrm{U}-\mathrm{Cd} 31.6 \rightarrow 14.7 \mu \mathrm{g} / \mathrm{g} \text { cr. }\end{array}$ \\
\hline Elinder et al. $(1985)^{7)}$ & $\begin{array}{l}13 \text { soldelers } \\
\text { Sweden } \\
7 \text { years }\end{array}$ & $\begin{array}{l}\mathrm{U}-\beta_{2} \mathrm{M} 664 \rightarrow 1,286 \mu \mathrm{g} / \mathrm{l} \\
\text { Prevalence of } \mathrm{U}-\beta_{2} \mathrm{M}>300 \mu \mathrm{g} / \mathrm{g} \text { cr. } \\
\quad 8 / 13 \rightarrow 9 / 13\end{array}$ & $\begin{array}{l}\text { Stopping of Cd containing materials } \\
\mathrm{U}-\mathrm{Cd} 59.8 \rightarrow 14.8 \mu \mathrm{g} / \mathrm{l}\end{array}$ \\
\hline Kasuya et al. $(1986)^{8)}$ & $\begin{array}{l}93 \text { residents in the Jinzu } \\
\text { River basin, Toyama, Japan } \\
10 \text { years }\end{array}$ & $\begin{array}{l}\text { Correlation coefficient of } U-\beta_{2} M \\
\text { in } 1975 \text { and } 1985=0.84 \\
U-\beta_{2} M \text { decreased more frequently among } \\
\text { those with initial } U-\beta_{2} M<1,000 \mu \mathrm{g} / \mathrm{g} \text { cr. } \\
\quad<40 \text { years old } \\
\quad \text { with residential period }<30 \text { years }\end{array}$ & Decreased \\
\hline Kido et al. $(1988)^{9)}$ & $\begin{array}{l}74 \text { residents in the Kakehashi } \\
\text { River basin, Ishikawa, Japan } \\
5 \text { years }\end{array}$ & $\mathrm{U}-\beta_{2} \mathrm{M} 857.6 \rightarrow 1,252.1 \mu \mathrm{g} / \mathrm{g}$ cr. & $\begin{array}{l}\mathrm{Cd} \text { in rice } 0.54-0.96 \rightarrow 0.06 \mathrm{mg} / \mathrm{kg}^{*} \\
\mathrm{U}-\mathrm{Cd} 10.0 \rightarrow 9.6 \mu \mathrm{g} / \mathrm{g} \text { cr. }\end{array}$ \\
\hline Roels et al. $(1989)^{6)}$ & $\begin{array}{l}23 \text { smelter workers } \\
\text { Belgium } \\
5 \text { years }\end{array}$ & $\begin{array}{l}\mathrm{U}-\beta_{2} \mathrm{M} 1,770 \rightarrow 2,580 \mu \mathrm{g} / 1 \\
\mathrm{~S}-\mathrm{Cr} 12.0 \rightarrow 15.1 \mathrm{mg} / \mathrm{l}^{*} \\
\mathrm{~S}-\beta_{2} \mathrm{M} 1.89 \rightarrow 3.00 \mathrm{mg} / \mathrm{l}^{*}\end{array}$ & $\begin{array}{l}\text { Removal from occupational exposure } \\
\text { B-Cd } 14.3 \rightarrow 9.7 \mu \mathrm{g} / 1^{*} \\
\text { U-Cd } 22.2 \rightarrow 18.0 \mu \mathrm{g} / 1^{*}\end{array}$ \\
\hline Iwata et al. $(1993)^{10)}$ & $\begin{array}{l}102 \text { residents in the Sasu area, } \\
\text { Tsushima Island, Japan } \\
10 \text { years }\end{array}$ & $\begin{array}{l}\text { Prevalence of } \mathrm{U}-\beta_{2} \mathrm{M}>1,000 \mu \mathrm{g} / \mathrm{g} \text { cr. } \\
\quad 17 / 52 \rightarrow 19 / 52 \\
\mathrm{U}-\beta_{2} \mathrm{M} 1,136 \rightarrow 2,000 \mu \mathrm{g} / \mathrm{g} \text { cr. } \\
\quad(>=40 \text { years old })\end{array}$ & $\begin{array}{l}\text { Dietary intake }>200 \mu \mathrm{g} / \text { day } \\
\rightarrow \text { approximately half } \\
\text { U-Cd } 11.4 \rightarrow 8.7 \mu \mathrm{g} / \mathrm{g} \mathrm{cr} \text {. } \\
\quad(>=40 \text { years old })\end{array}$ \\
\hline Roels et al. $(1997)^{13)}$ & $\begin{array}{l}32 \text { Cd production workers, } \\
\text { Belgium } \\
9 \text { years }\end{array}$ & $\begin{array}{l}\mathrm{U}-\beta_{2} \mathrm{M} 697 \rightarrow 262 \mu \mathrm{g} / \mathrm{g} \text { cr. }(\mathrm{N}=5) \\
\quad \text { initial } \mathrm{U}-\beta_{2} \mathrm{M} 300-1,500 \mu \mathrm{g} / \mathrm{g} \text { cr.) } \\
\mathrm{U}-\beta_{2} \mathrm{M} 8,959 \rightarrow 18,082 \mu \mathrm{g} / \mathrm{g} \text { cr. }(\mathrm{N}=10) \\
\quad \text { initial } \mathrm{U}-\beta_{2} \mathrm{M}>=1,500 \mu \mathrm{g} / \mathrm{g} \text { cr.) }\end{array}$ & $\begin{array}{l}\text { Removal from occupational exposure } \\
\text { B-Cd } 11.5 \rightarrow 5.7 \mu \mathrm{g} / \mathrm{l}(\mathrm{N}=5) \\
\mathrm{U}-\mathrm{Cd} 12.9 \rightarrow 7.5 \mu \mathrm{g} / \mathrm{g} \text { cr. }(\mathrm{N}=5) \\
\mathrm{B}-\mathrm{Cd} 15.1 \rightarrow 8.5 \mu \mathrm{g} / \mathrm{l}(\mathrm{N}=10) \\
\mathrm{U}-\mathrm{Cd} 16.7 \rightarrow 11.6 \mu \mathrm{g} / \mathrm{g} \text { cr. }(\mathrm{N}=10)\end{array}$ \\
\hline Järup et al. (1997) ${ }^{14)}$ & $\begin{array}{l}46 \text { solderers exposed to } \mathrm{Cd} \text {, } \\
\text { Sweden, } 9 \text { years }\end{array}$ & $\begin{array}{l}\text { Irreversible in most cases } \\
\qquad\left(\mathrm{U}-\beta_{2} \mathrm{M}>=300 \mu \mathrm{g} / \mathrm{g} \text { cr. }\right)\end{array}$ & $\begin{array}{l}\text { Stopping of Cd containing solders } \\
\mathrm{U}-\mathrm{Cd} 8.6 \rightarrow 3.7 \mu \mathrm{g} / \mathrm{g} \mathrm{cr}^{*}\end{array}$ \\
\hline Fan et al. $(1998)^{12)}$ & $\begin{array}{l}173 \text { females living in the Jinzu } \\
\text { River basin, Toyama, Japan } \\
11 \text { years }\end{array}$ & $\begin{array}{l}\mathrm{U}-\beta_{2} \mathrm{M} 1,410 \rightarrow 3,820 \mu \mathrm{g} / \mathrm{g} \text { cr. } \\
\text { Prevalence of } \mathrm{U}-\beta_{2} \mathrm{M}>1,000 \mu \mathrm{g} / \mathrm{g} \text { cr. } \\
\quad 94 / 173 \rightarrow 122 / 173\end{array}$ & $\begin{array}{l}\text { Cd in polished rice } \\
0.28 \rightarrow 0.13 \mathrm{mg} / \mathrm{kg}\end{array}$ \\
\hline Hots et al. (1999) ${ }^{16)}$ & $\begin{array}{l}593 \text { subjects enrolled in the } \\
\text { Cadmibel Study, Belgium } \\
5 \text { years }\end{array}$ & $\begin{array}{l}\mathrm{U}-\beta_{2} \mathrm{M} 73 \rightarrow 63 \mu \mathrm{g} / \mathrm{g} \text { cr. (Men) } \\
\mathrm{U}-\beta_{2} \mathrm{M} 73 \rightarrow 63 \mu \mathrm{g} / \mathrm{g} \text { cr. (Women) } \\
\mathrm{CCr} 93.8 \rightarrow 91.6 \mathrm{ml} / \mathrm{min} \text {. (Men)* } \\
\mathrm{CCr} 82.0 \rightarrow 82.3 \mathrm{ml} / \mathrm{min} \text {. (Women)* }\end{array}$ & $\begin{array}{l}\text { Reduction in environmental exposure } \\
\text { B-Cd } 1.06 \rightarrow 0.69 \mu \mathrm{g} / 1 \text { (Men) } \\
\text { B-Cd } 1.23 \rightarrow 0.88 \mu \mathrm{g} / \text { l (Women) } \\
\text { U-Cd } 1.00 \rightarrow 0.84 \mu \mathrm{g} / \text { day (Men) } \\
\text { U-Cd } 0.99 \rightarrow 0.85 \mu \mathrm{g} / \text { day (Women) }\end{array}$ \\
\hline
\end{tabular}

U- $\beta_{2} M$, urinary $\beta_{2}$-microglobulin; cr., creatinine; B-Cd, blood cadmium; U-Cd, urinary cadmium; S-Cr, serum creatinine;

S- $\beta_{2} \mathrm{M}$, serum $\beta_{2}$-microglobulin; Ccr, creatinine clearance.

* Arithmetic means are indicated. Otherwise, geometric means are indicated. 
のまま示した。なお，著者らは， $1,000 \mu \mathrm{g} / \mathrm{g}$ cr. を採用し ているが，これは，Cd污染地域では高齢者が多いことや 非污染地域住民の 95 パーセンタイル值がこの值に近い ことによる。また, 血液中 $\mathrm{Cd}$ 濃度は数週から数力月前 の曝露を, 尿中 $\mathrm{Cd}$ 濃度は腎皮質中 $\mathrm{Cd}$ 濃度または体内 蓄積量を主として反映するものとされている ${ }^{2)}$ 。

Roels $ら^{5)}$ は, 11 人の Cd 作業者について, 職業性曝露 解消の前後 3.6 年の間に尿中 $\beta_{2}-\mathrm{MG}$ 濃度の測定を 2 回行 い，幾何平均值が 4.9 倍に上昇したこと，また，この間 に低分子量蛋白尿 $\left(\beta_{2}-\mathrm{MG}>=200 \mu \mathrm{g} / \mathrm{g} \mathrm{cr}\right.$. $)$ が消失した人 はいなかった（0人/ 8 人）ことを報告した。この調査は retrospective なものであったため, その後, 彼らは 23 人 の非鉄金属精錬所の労働者について 5 年間の prospective study を行った ${ }^{6)}$ 。この調査では，尿中 $\beta_{2}-\mathrm{MG}$ 濃度 $(\mu \mathrm{g} / \mathrm{l})$ の幾何平均值は約 1.5 倍に上昇し, また，加齢のみでは 説明できない程度の系球体機能の低下 (血清 $\beta_{2}-\mathrm{MG}$ 濃度 およびクレアチニン濃度の上昇）も認められた。Elinder $ら^{7)}$ による $\mathrm{Cd}$ 作業者 13 人についての 7 年間の調査で は，ベースライン時に尿中 $\beta_{2}-\mathrm{MG}$ が一時的に上昇して いたと考えられた 1 人を除いて, 尿中 $\beta_{2}-\mathrm{MG}$ の排泄増加 ( $>300 \mu \mathrm{g} / \mathrm{g}$ cr.) は職業性曝露の解消後も消失しなかっ た。また， 2 人では，新たに低分子量蛋白尿が出現した。 加須屋ら ${ }^{8)}$ は, 富山県神通川流域のイタイイタイ病患 者家族 93 人について, 1975 年と 1985 年の 2 回, 尿中 $\beta_{2}-$ MG 濃度を測定した。両年の測定值の間には相関係数 0.84 と高い相関が認められ, 全体的には低分子量蛋白尿 の持続が示唆された。しかし, 詳細に検討すると, 尿中 $\beta_{2}-\mathrm{MG}$ 濃度が 10 分の 1 以下に低下している例があり,こ れらは 1975 年の尿中 $\beta_{2}-\mathrm{MG}$ 濃度が $1,000 \mathrm{~g} / \mathrm{g}$ cr. 未満, 年 齢が 40 歳未満で, 污染地域居住年数が 30 年未満の人に
多かった。Kido ら ${ }^{9}$ は，石川県梯川流域で最も Cd 污染 の強かった地域の住民 74 人について，1981 年と 1986 年 の 2 回，尿中 $\beta_{2}-\mathrm{MG}$ 濃度を測定した。1979 年に污染土 壌が復元され, 米中 Cd 濃度が低下したにもかかわらず, 尿中 $\beta_{2}-\mathrm{MG}$ の幾何平均值は約 1.5 倍に上昇していた。な お，尿中 $\mathrm{Cd}$ 濃度には有意な変化は見られなかった。著 者ら ${ }^{10)}$ は, 長崎県対馬の Cd 污染地域住民 102 人につい て, 尿中 $\beta_{2}$-MG 排泄量を 1979 年から 1989 年まで追跡し た。Fig. 1 に, 最初と最後の時点における尿中 $\beta_{2}-\mathrm{MG}$ 濃 度の変化と年齢との関係を示す。污染土壌復元工事が 1981 年に終了した結果, 平均 Cd 攝取量が $200 \mu \mathrm{g}$ /日以上 から約半分に低下し, また, 尿中 $\mathrm{Cd}$ 濃度の幾何平均値 は約 0.7 倍に低下していた。しかし, 低分子量蛋白尿 （尿中 $\beta_{2}-\mathrm{MG}>1,000 \mu \mathrm{g} / \mathrm{g} \mathrm{cr}$.) は全員で不可逆性であり， 40 歳以上または最初の尿中 $\beta_{2}-\mathrm{MG}$ 濃度が $1,000 \mu \mathrm{g} / \mathrm{g}$ cr. を超えた群では, 尿中 $\beta_{2}-\mathrm{MG}$ 濃度の幾何平均值が約 1.8 倍に上昇していた。さらに, この調查においては, $\mathrm{Cd}$ による腎障害の重い人ほど死亡により追跡から脱落 しやすいことが指摘された。1996 年までの継続調査で も同様の結果であり，尿中 $\beta_{2}-\mathrm{MG}$ 濃度の上昇が見られ た ${ }^{11)}$ 。㚞ら ${ }^{12)}$ は, 富山県神通川流域 Cd 污染地域の女性 住民 173 人について, 1983-1984 年と 1994-1995 年の 2 回, 調査を行った。この間, 精白米中 $\mathrm{Cd}$ 濃度の幾何平 均值が $0.28 \mathrm{mg} / \mathrm{kg}$ から $0.13 \mathrm{mg} / \mathrm{kg}$ に低下していたが, 尿中 $\beta_{2}-\mathrm{MG}$ 濃度の幾何平均值は $1,410 \mu \mathrm{g} / \mathrm{g}$ cr. から 3,820 $\mu \mathrm{g} / \mathrm{g}$ cr. (2.7 倍) に上昇していた。また, 低分子量蛋白 尿（尿中 $\beta_{2}-\mathrm{MG}>1,000 \mu \mathrm{g} / \mathrm{g}$ cr.） の有病割合は， $94 / 173$ (54.3\%) から 122/173（70.5\%）に増加していた。ただ し, この地域では, Cd 污染田の復元工事は一部しか完了 しておらず，過剩な $\mathrm{Cd}$ 曝露がいまだ続いていると見る
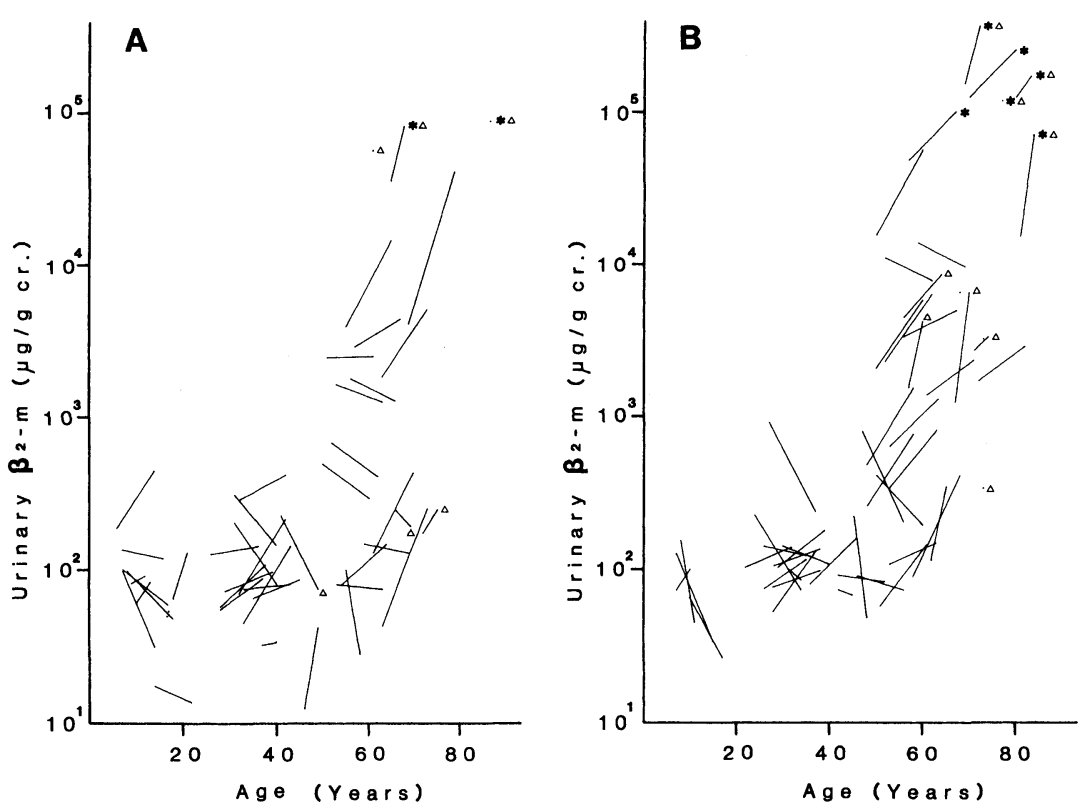

Fig. 1 Change in urinary $\beta_{2}$-microglobulin excretion between the first and last examination in men (A) and women (B) in relation to age. $*=$ subjects recognized as requiring observation; $\triangle=$ subjects who died during the observation period. 
ベきである。

Roels ら ${ }^{13)}$ は, 亜鉛-Cd生産プラントの労働者について 曝露軽減の前後約 9 年間に 2 回の調査を行った。曝露軽 減前の尿中 $\beta_{2}-\mathrm{MG}$ 濃度が $300-1,500 \mu \mathrm{g} / \mathrm{g}$ cr. で，かつ尿 中 $\mathrm{Cd}$ 濃度が一度も $20 \mu \mathrm{g} / \mathrm{g} \mathrm{cr}$. を超えたことがなかった 5 人では, $\beta_{2}-\mathrm{MG}$ 濃度および尿中 RBP 濃度の低下が見られ た。一方, 曝露軽減前の尿中 $\beta_{2}-\mathrm{MG}$ 濃度が $1,500 \mu \mathrm{g} / \mathrm{g} \mathrm{cr}$ を超えており，かつ尿中 Cd 濃度が $20 \mu \mathrm{g} / \mathrm{g}$ cr. を超えた 10 人では，尿中 $\beta_{2}-\mathrm{MG}$ 濃度および尿中 RBP 濃度はさら に上昇していた。これらの結果から，体内 $\mathrm{Cd}$ 蓄積量が それほど多くない人では軽度な低分子量蛋白尿は可逆性 であるが，より重度の低分子量蛋白尿は不可逆性であろ うとした。Järup ら ${ }^{14)}$ は，46 人の Cd 作業者（曝露は 1978 年に軽減）について, 1984 年と 1993 年の 2 回調査を行っ たところ，尿中 $\mathrm{Cd}$ 濃度の幾何平均值は $57 \%$ 低下したが， 低分子量蛋白尿（尿中 $\beta_{2}-\mathrm{MG}>300 \mu \mathrm{g} / \mathrm{g}$ cr.） はほとんど の人で持続性であったと報告した。

ベルギーの低濃度 Cd 污染地域における断面調查 （Cadmibel Study）で，尿中 Cd 排泄量と RBP， N-acetyl- $\beta$ D-glucosaminidase (NAG), $\beta_{2}-\mathrm{MG}$, アミノ酸およびカル シウムの尿中排泄量との間に有意な関連があり，尿中 Cd排泄量が 2 $-4 \mu \mathrm{g} /$ 日を超えると上記 4 マーカーの尿中排

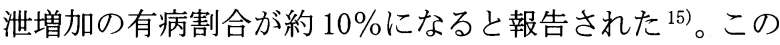
集団の 5 年後の追跡調査では，環境中 $\mathrm{Cd}$ 排出量の減少 や井戸水・自家野菜の摄取の制限の結果，血中 $\mathrm{Cd}$ 濃度 の幾何平均值は 28-35\%低下し，尿中 $\mathrm{Cd}$ 濃度の幾何平 均值は 14-16\%低下した。アルブミン, RBP, NAG, $\beta_{2}$ MG，カルシウムの尿中排泄量およびクレアチニンクリ アランスの值には悪化は認められず，項目によっては改 善傾向が見られた ${ }^{16)}$ 。ただし，この集団全体のベースラ イン時における尿中 $\mathrm{Cd}$ 排泄量の幾何平均値は約 $1.0 \mu \mathrm{g} /$ 日であり，日本の非污染地域の值 $(2.3 \mu \mathrm{g} / \mathrm{g} \mathrm{cr} \text {. })^{17)}$ に比 較してもかなり低い。したがって，この調査結果は， $\mathrm{Cd}$ 曝露労働者や日本の $\mathrm{Cd}$ 污染地域住民のものと同列に論 ずることはできない。

この他，表には示していないが，系球体機能を含む他 の腎機能についての追跡調査がある。原田ら ${ }^{18)}$ は, 長崎 県対馬の Cd 污染地域において, 重症の $\mathrm{Cd}$ 腎障害のため に要経過観察と判定された 14 人の血清クレアチニン, クレアチニンクリアランス, 血液中 $\mathrm{HCO}_{3}{ }^{-}$, 尿細管リン 再吸収率について 9 年間の経過観察を行い, 污染改善後 にもかかわらず，すべての項目が徐々に悪化する傾向を 認めた。Kido ら ${ }^{19)}$ も，石川県梯川流域の Cd 污染地域住 民 21 人について, 曝露軽減後に血清クレアチニン濃度 の上昇と血液中 $\mathrm{HCO}_{3}{ }^{-}$濃度の低下を認めている。Järup $ら^{20)}$ は, 16 人の $\mathrm{Cd}$ 作業者（文献 14 の対象者 46 人に含 まれる)について, 1984 年と 1989 年の 2 回, 系球体ろ過 值を測定したところ，系球体ろ過值の低下の度合は空気 中 Cdの累積曝露量と関連していたと報告した（相関係 数 $=-0.45, \mathrm{p}=0.08)$ 。

以上のデータは, $\mathrm{Cd}$ 曝露による低分子量蛋白尿（ $\beta_{2}-$
MG $>300-1,000 \mu \mathrm{g} / \mathrm{g}$ cr.） は, 多くの場合, 曝露軽減後も 不可逆性・進行性であることを示している。これは, $\mathrm{Cd}$ の生物学的半減期が非常に長く, 肝臓に蓄積された $\mathrm{Cd}$ が Cd-メタロチオネインの形で腎臓へ運ばれ，尿細管細 胞を傷害し続けるためと考えられる。Cd 腎障害の予後 が， $\mathrm{Cd}$ 曝露軽減前の曝露強度や体内 $\mathrm{Cd}$ 蓄積量によって 影響を受ける可能性がある。例えば, Roels らの調査 ${ }^{5)}$ では, 腎障害の進展速度が非常に速い印象を受けるが, この集団の最初の時点での血中 $\mathrm{Cd}$ 濃度の幾何平均值は $31.9 \mu \mathrm{g} / \mathrm{g}$ cr. と高く, 職業性曝露解消前の曝露が非常に 強かったことが推察される。また，いくつかの調査にお いて, 曝露軽減後に糸球体機能の低下傾向が見られてい る。

\section{2. 環境 Cd 曝露, 腎尿細管障害と死亡率との関連}

$\mathrm{Cd}$ 曝露労働者におけるコホート調査では, 1960 年代 から肺がんおよび前立腺がんのリスクの上昇が問題視 されてきたが,これについては, Elinder と Kjellström ${ }^{21)}$ によって詳しくレビューされている。1993 年に, International Agency for Research on Cancer（IARC）は，Cd お よびCd 化合物を発がん物質（グループ1）であると結論 したが 22), 最近の論文では, 前立腺がんについてはリス クの上昇は観察されておらず23)，肺がんについては，喫 煙, 砒素化合物 (非鉄金属精錬所)，ニッケル (ニッケル カドミウム電池工場）の曝露による交絡が問題になるよ うである ${ }^{23,24)}$ 。また, Cd 曝露労働者の死亡率・がん罹患 率についてのコホート調査は, 追跡が開始された時期が 早いこともあり, 多くの調査において Cd 曝露または $\mathrm{Cd}$ による健康影響に関する信頼性の高い biological indicator が用いられていないなどの問題点がある。一方，環境 （経口） $\mathrm{Cd}$ 曝露では, 職業性 (経気道) 曝露と異なり, 肺がんのリスクは問題になっておらず，また，前立腺が んのリスクの有意な上昇を示した報告はない。ここで は, Cd 污染地域で問題になっている腎尿細管障害と死 亡率との関連を中心に述べることにする。

Table 2 に, Cd 污染地域住民の死亡率に関する主な コホート調査について, 対象集団, 追跡期間, 標準化 死亡比 (Standardized mortality ratio, SMR) または率比 (Rate ratio, RR)，および対照集団をまとめて示した。重 松ら ${ }^{25,26)}$ は, 富山県神通川流域 Cd 污染地域（人口約 34,000 人）の総死亡率（1948-1977 年）は，男女とも同 県内の非污染地域のそれに比べて有意に低いこと，ま た, 男性では, 污染の程度が高くなるにつれて SMR が 低くなることを報告した。一方, Nakagawa $~^{27)}$ は, 石 川県梯川流域 Cd 污染地域の男性住民 1,078 人において, 尿中 RBP 陰性群（一元免疫拡散法, <4 mg/l） を基準と した時の尿中 RBP 陽性群の SMR が 191 であり，100よ り有意に高いことを報告した。そして, 重松らの結果 は，対照地域として山間部を選んだことに起因する選択 バイアスによるものであろうとした。しかし，重松らの 調査 ${ }^{25,26)}$ では, 個人の Cd 曝露や $\mathrm{Cd}$ による健康影響に 
Table 2 Cohort studies on the all cause mortality among populations exposed to environmental cadmium

\begin{tabular}{|c|c|c|c|c|}
\hline Author (year) & $\begin{array}{l}\text { Area, Country } \\
\text { (Follow-up period) } \\
\text { (Number of subjects) }\end{array}$ & Cohort & $\begin{array}{l}\text { SMR or RR } \\
\text { (p-value or } 95 \% \mathrm{CI} \text { ) }\end{array}$ & Reference group \\
\hline $\begin{array}{l}\text { Shigematsu et al. } \\
(1980)^{25,26)}\end{array}$ & $\begin{array}{l}\text { Jinzu River basin, } \\
\text { Toyama, Japan } \\
(1948-1977) \\
(\mathrm{N}=33,403-33,855)\end{array}$ & All residents & $\begin{array}{l}88(\mathrm{p}<0.01)(\text { Men }) \\
89(\mathrm{p}<0.01)(\text { Women }) \\
\text { (polluted + reference areas }=100)\end{array}$ & $\begin{array}{l}\text { Non-polluted area } \\
\text { in the same prefecture }\end{array}$ \\
\hline $\begin{array}{l}\text { Lauwerys and De Wals } \\
(1981)^{33)}\end{array}$ & $\begin{array}{l}\text { Liege, Belgium } \\
(1969-1976) \\
(\mathrm{N}=617,572)\end{array}$ & All residents & $\begin{array}{l}107(\mathrm{p}<0.05) \text { (All cause) } \\
196(\mathrm{p}<0.05) \\
\text { (Nephritis, Nephrosis) }\end{array}$ & $\begin{array}{l}\text { Total Belgian } \\
\text { population }\end{array}$ \\
\hline Inskip et al. $(1982)^{35)}$ & $\begin{array}{l}\text { Shipham, U.K. } \\
(1939-1979) \\
(\mathrm{N}=501)\end{array}$ & All residents & $\begin{array}{l}89(p<0.05) \\
95(p>0.05)\end{array}$ & $\begin{array}{l}\text { England and Wales } \\
\text { South-west England }\end{array}$ \\
\hline $\begin{array}{l}\text { Nakagawa et al. } \\
(1987)^{27)}\end{array}$ & $\begin{array}{l}\text { Kakehashi River basin, } \\
\text { Ishikawa, Japan } \\
(1974 \text { or } 1975-1981 \text { or } 1982) \\
(\mathrm{N}=2,414)\end{array}$ & U-RBP $>=4 \mathrm{mg} / \mathrm{l}$ & $\begin{array}{l}191(p<0.001)(\text { Men }) \\
119(p>0.05)(\text { Women })\end{array}$ & $\mathrm{U}-\mathrm{RBP}<4 \mathrm{mg} / \mathrm{l}$ \\
\hline Iwata et al. $(1991)^{29)}$ & $\begin{array}{l}\text { Sasu area, Tsushima Island, } \\
\text { Japan }(1982-1989) \\
(\mathrm{N}=275)\end{array}$ & $\begin{array}{l}\mathrm{U}-\beta_{2} \mathrm{M}>1,000 \mu \mathrm{g} / \mathrm{g} \text { cr. } \\
\mathrm{U}-\beta_{2} \mathrm{M}<1,000 \mu \mathrm{g} / \mathrm{g} \text { cr. } \\
\text { All residents }\end{array}$ & $\begin{array}{l}215(93-424) \text { (Men) } \\
187(116-287) \text { (Women) } \\
76(41-131) \text { (Men) } \\
35(7-103) \text { (Women) } \\
101(63-155) \text { (Men) } \\
126(81-186) \text { (Women) }\end{array}$ & $\begin{array}{l}\text { Total population of } \\
\text { Tsushima Island }\end{array}$ \\
\hline Iwata et al. $(1992)^{30)}$ & $\begin{array}{l}\text { Kosaka Town, Akita, } \\
\text { Japan }(1975 \text { or } 1977-1990) \\
(N=230)\end{array}$ & All residents & $\begin{array}{l}\mathrm{RR} \text { associated with } \\
10 \text {-fold increase in } \mathrm{U}-\beta_{2} \mathrm{M} \\
=1.44(1.02-2.04) \text { (Women) }\end{array}$ & - \\
\hline Nishijo et al. $(1994)^{31)}$ & $\begin{array}{l}\text { Kakehashi River basin, } \\
\text { Ishikawa, Japan } \\
(1981 \text { or 1982-1991) } \\
(\mathrm{N}=3,178)\end{array}$ & $\begin{array}{l}\mathrm{U}-\beta_{2} \mathrm{M}>=1,000 \mu \mathrm{g} / \mathrm{g} \mathrm{cr} . \\
\mathrm{U}-\beta_{2} \mathrm{M}<1,000 \mu \mathrm{g} / \mathrm{g} \text { cr. } \\
\text { All residents }\end{array}$ & $\begin{array}{l}129.5(104.0-155.0) \text { (Men) } \\
146.0(121.5-170.6) \text { (Women) } \\
78.0(67.1-88.9) \text { (Men) } \\
77.2(64.5-89.9) \text { (Women) } \\
87.7(77.5-97.9) \text { (Men) } \\
100.3 \text { (88.5-112.1) (Women) }\end{array}$ & $\begin{array}{l}\text { Total Japanese } \\
\text { population }\end{array}$ \\
\hline Nishijo et al. $(1999)^{32)}$ & $\begin{array}{l}\text { Kakehashi River basin, } \\
\text { Ishikawa, Japan } \\
(1981 \text { or } 1982-1997) \\
(\mathrm{N}=3,119)\end{array}$ & $\mathrm{U}-\mathrm{Cd}>=10 \mu \mathrm{g} / \mathrm{g}$ cr. & $\begin{array}{l}\mathrm{p}<0.1 \text { (Men, } 50-59 \text { years) } \\
\mathrm{p}<0.1 \text { (Men, } 60-69 \text { years) } \\
\mathrm{p}>0.05 \text { (Men, } 70-79 \text { years) } \\
\mathrm{p}>0.05 \text { (Men, }>=80 \text { years) } \\
\mathrm{p}>0.05 \text { (Women, } 50-59 \text { years) } \\
\mathrm{p}<0.1 \text { (Women, } 60-69 \text { years) } \\
\mathrm{p}<0.05 \text { (Women, } 70-79 \text { years) } \\
\mathrm{p}>0.05 \text { (Women, }>=80 \text { years) }\end{array}$ & $\mathrm{U}-\mathrm{Cd}<10 \mu \mathrm{g} / \mathrm{g}$ cr. \\
\hline Elliott et al. $(2000)^{36)}$ & $\begin{array}{l}\text { Shipham, U.K. } \\
(1939-1997) \\
(\mathrm{N}=351)\end{array}$ & All residents & $90(79-101)$ & South-west England \\
\hline \multirow[t]{2}{*}{ Arisawa et al. $(2001)^{38)}$} & $\begin{array}{l}\text { Sasu area, Tsushima Island, } \\
\text { Japan }(1982-1997) \\
(\mathrm{N}=275)\end{array}$ & $\begin{array}{l}\mathrm{U}-\beta_{2} \mathrm{M}>=1,000 \mu \mathrm{g} / \mathrm{g} \text { cr. } \\
\mathrm{U}-\beta_{2} \mathrm{M}<1,000 \mu \mathrm{g} / \mathrm{g} \text { cr. } \\
\text { All residents }\end{array}$ & $\begin{array}{c}138(101-183) \\
66(49-87) \\
90(73-109)\end{array}$ & $\begin{array}{l}\text { Total population of } \\
\text { Tsushima Island }\end{array}$ \\
\hline & & $\begin{array}{l}\mathrm{S}-\beta_{2} \mathrm{M}>=2.3 \mathrm{mg} / \mathrm{l} \\
\mathrm{U}-\beta_{2} \mathrm{M}>=1,000 \mu \mathrm{g} / \mathrm{g} \text { cr. } \\
\mathrm{S}-\beta_{2} \mathrm{M}>=2.3 \mathrm{mg} / \mathrm{l} \\
\mathrm{S}-\mathrm{Cr}>=1.2 \mathrm{mg} / \mathrm{dl} \\
\mathrm{C}-\beta_{2} \mathrm{M}>=1 \% \mathrm{CCr} \\
\mathrm{U}-\beta_{2} \mathrm{M}>=1,000 \mu \mathrm{g} / \mathrm{g} \mathrm{cr} .\end{array}$ & $\begin{array}{l}2.68(1.02-7.03) \text { (Men) } \\
2.05(0.94-4.47) \text { (Men) } \\
1.97(0.99-3.90) \text { (Women) } \\
3.04(1.50-6.15) \text { (Women) } \\
2.44(1.30-4.60) \text { (Women) } \\
2.05 \text { (1.05-4.01) (Women) }\end{array}$ & $\begin{array}{l}\mathrm{S}-\beta_{2} \mathrm{M}<2.3 \mathrm{mg} / \mathrm{l} \\
\mathrm{U}-\beta_{2} \mathrm{M}<1,000 \mu \mathrm{g} / \mathrm{g} \text { cr. } \\
\mathrm{S}-\beta_{2} \mathrm{M}<2.3 \mathrm{mg} / \mathrm{l} \\
\mathrm{S}-\mathrm{Cr}<1.2 \mathrm{mg} / \mathrm{dl} \\
\mathrm{C}-\beta_{2} \mathrm{M}<1 \% \mathrm{CCr} \\
\mathrm{U}-\beta_{2} \mathrm{M}<1,000 \mu \mathrm{g} / \mathrm{g} \text { cr. }\end{array}$ \\
\hline
\end{tabular}

SMR, standardized mortality ratio; RR, rate ratio; $\mathrm{CI}$, confidence interval; U-RBP, urinary retinol-binding protein;

U- $\beta_{2} \mathrm{M}$, urinary $\beta_{2}$-microglobulin; cr., creatinine; S- $\beta_{2} \mathrm{M}$, serum $\beta_{2}$-microglobulin; S-Cr, serum creatinine; C- $\beta_{2} \mathrm{M}, \beta_{2}$-microglobulin clearance; $\mathrm{CCr}$, creatinine clearance.

関する情報が用いられておらず（つまり， ecologic study であり，原因推論上，限界がある $\left.{ }^{28)}\right)$, Nakagawa らの調 査 ${ }^{27)}$ では, 尿中低分子量蛋白の測定が半定量的なもので
あり，また，外部コントロール集団が用いられていなか った。そこで, 著者らは, これらの点を考慮して, 長 崎県対馬の Cd 污染地域においてコホート調査を行っ 
た ${ }^{29)}$ 。同地域の 40 歳以上の男女 275 人を 1982 年から 1989 年まで 7 年間追跡したところ, Cox 回帰分析を用い て年齢を調整しても，男女とも尿中 $\beta_{2}-\mathrm{MG}$, 血清 $\beta_{2}-\mathrm{MG}$ および血清クレアチニンの高值が総死亡率の上昇と密 接に関連していることが明らかとなった。しかし，尿 中 $\beta_{2}-\mathrm{MG} 1,000 \mu \mathrm{g} / \mathrm{g} \mathrm{cr}$. 未満群の死亡率が低い傾向が あったため, 対馬全体を基準集団とした時の地域全体の SMR は，男性で 101（95\%信頼区間 [CI］63-155），女性 で 126 (95\%CI 81-186) であり，有意な上昇は見られな かった。秋田県小坂町における調査では, Cd 污染地域内 のみでの検討ではあるが, 女性において $\beta_{2}-\mathrm{MG}$ および総 アミノ窒素の尿中排泄量の高值が死亡率の上昇と有意に 関連していた ${ }^{30)}$ 。尿中 $\beta_{2}-\mathrm{MG}$ 排泄量が 10 倍になること に伴う年齢調整ハザード比は $1.44 （ 95 \%$ CI 1.02-2.04） と推定された。

その後, 石川県梯川流域住民 3,178 人について 7.9 年 間の追跡調査が行われ，男女とも $\beta_{2}-\mathrm{MG}$, 総蛋白および 総アミノ窒素の尿中濃度と死亡率との間に有意な関連が あることが報告された ${ }^{31)}$ 。しかし，日本全国を基準とし た時の地域全体の SMR は，男性で 87.7（95\%CI 77.597.9)，女性で 100.3 (95\%CI 88.5-112.1) であり，上昇 は見られず，男性では逆に 100 より有意に低かった。こ の理由として, Nishijo らは, Cdに対する感受性の高い 人が早期に死亡したための survivor effect が考えられる とした。最近, 同地域の 50-69 歳の男性および 60-79 歳 の女性において, 尿中 $\mathrm{Cd}$ 濃度 $10 \mu \mathrm{g} / \mathrm{g}$ cr. 以上群の死亡 率が $10 \mu \mathrm{g} / \mathrm{g}$ cr. 未満群より有意またはほぼ有意に高いこ とが報告された ${ }^{32)}$ 。しかし，率比の推定および外部対照 集団との死亡率の比較は行われなかった。

ベルギーでは，Lauwerys と De Wals ${ }^{33)}$ が，低濃度 $\mathrm{Cd}$ 污染地域（Liege，人口約 62 万）における腎炎・ネフロ 一ゼの SMRが 196 であり，100より有意に高いことを報 告した。しかし，この地域の女性における尿中 $\mathrm{Cd}$ 濃度 の平均值は， $2.2 \mu \mathrm{g} / \mathrm{day}$ (範囲 0.4-8.8） と報告されてお $\eta^{34)}$, 日本の非污染地域の值 ${ }^{17)}$ とほぼ同じである。英国 の高濃度 Cd 污染地域（Shipham）の住民 501 人における 追跡調查（1939-1979 年）では，地域全体の SMR は 89 (England and Wales を基準) および95（South-west England 基準) であり，上昇は認められなかった ${ }^{35)}$ 。ま た，1997 年までの継続調査でも，地域全体の SMR は 90 (95\%CI 79-101， South-west England を基準）であり，上 昇は認められなかった ${ }^{36)}$ 。ただし，この地域における食 事からの平均 $\mathrm{Cd}$ 摂取量は約 $30 \mu \mathrm{g} /$ 日 と報告されており, 日本の非污染地域の值 (幾何平均 $=25 \mu \mathrm{g} /$ 日) ${ }^{37}$ ) とほぼ同 じである。したがって，地域住民が過剩に Cd に曝露さ れているとは言えない。

Fig. 2 に, 対馬の Cd 污染地域住民 275 人（対象者は文 献 29 と同じ）における，1982 年から 1997 年までの年齢 (70 歳以上, 70 歳未満) および尿中 $\beta_{2}-\mathrm{MG}$ 排泄量（ $\beta_{2}-$ $\mathrm{MG} 1,000 \mu \mathrm{g} / \mathrm{g} \mathrm{cr}$. 以上, $1,000 \mu \mathrm{g} / \mathrm{g}$ cr. 未満）別の累積生 存割合を示した ${ }^{38)}$ 。男性の 70 歳以上を除き, 尿中 $\beta_{2}-\mathrm{MG}$
$1,000 \mu \mathrm{g} / \mathrm{g}$ cr. 以上群の生存割合は $1,000 \mu \mathrm{g} / \mathrm{g}$ cr. 未満群の それに比べて有意に低かった（Log-rank 検定）。また，年 歯, Body Mass Index, 血圧值, 血清コレステロール值の 影響を補正しても，男性では血清 $\beta_{2}-\mathrm{MG}$ および尿中 $\beta_{2}$ $\mathrm{MG}$ の高值, 女性では血清クレアチニン, $\beta_{2}-\mathrm{MG}$ クリア ランスおよび尿中 $\beta_{2}-\mathrm{MG}$ の高值が死亡率の上昇と有意 またはほぼ有意に関連しており，ハザード比は 2 を超え ていた。尿中 Cd 濃度と死亡率との間には関連は見られ なかったが,これは, 対象者の中に重症の $\mathrm{Cd}$ 腎障害を 持つ人が含まれていたためと思われる。すなわち，この ような例では, 腎の萎縮・繊維化により，腎皮質中 $\mathrm{Cd}$ 濃 度が正常人と比較しても低下しており ${ }^{39)}$ ，尿中 $\mathrm{Cd}$ 濃度 はもはや体内 $\mathrm{Cd}$ 蓄積量を反映しないと考えられる。対 馬全体を基準集団とすると, 地域全体，尿中 $\beta_{2}$-MG $1,000 \mu \mathrm{g} / \mathrm{g}$ cr. 以上群および $1,000 \mu \mathrm{g} / \mathrm{g}$ cr. 未満群の SMR は，それぞれ 90 (95\%CI 73-109)，138（95\%CI 101-183） および 66 （95\%CI 49-87）であった。長崎県全体を基準 集団としても結果に大きな違いはなく, 選択バイアスの 影響は考えにくかった。尿中 $\beta_{2}-\mathrm{MG} 1,000 \mu \mathrm{g} / \mathrm{g}$ cr. 未満 群の死亡率が低いことの生物学的機序としては, メタロ チオネインによる抗酸化作用の可能性 ${ }^{40)}$ を考えた。

$\mathrm{Cd}$ 污染地域住民のがん罹患率についての報告は少 ない。ElliottらのShiphamにおける調査 ${ }^{36)}$ では, 地域全 体の全悪性腫瘍の標準化罹患比（Standardized Incidence Ratio, SIR）は 167 (95\%CI 106-250）と高かったが，対 照地域 (Hutton) でもSIRは 167 （95\%CI 105-253）と高 くなっており, 解釈は難しい。著者らの対馬の污染地域 における調査 ${ }^{38)}$ では, 対馬全体を基準とした時の地域全 体, 尿中 $\beta_{2}-\mathrm{MG} 1,000 \mu \mathrm{g} / \mathrm{g}$ cr. 以上群および $1,000 \mu \mathrm{g} / \mathrm{g}$ cr. 未満群の全がんの SIR は, それぞれ 71 (95\%CI 44-107), 103 (95\%CI 41-212）および58（95\%CI 32-97）であり, $1,000 \mu \mathrm{g} / \mathrm{g}$ cr. 未満群ではがんの罹患率が有意に低かっ た。肺がんおよび前立腺がんのリスクの上昇は見られな かった。

以上の結果を総合すると，（1）Cd 污染地域住民にお いて，尿細管機能および糸球体機能の低下は総死亡率 の上昇と密接に関連している，（2）結果の解釈は研究 者によって異なる部分はあるが, 尿中 $\beta_{2}-\mathrm{MG}$ 濃度が $1,000 \mu \mathrm{g} / \mathrm{g}$ cr. 未満の人の死亡率が低いために, 污染地域 全体では，必ずしも総死亡率は上昇しない，（3）現時点 では, Cd 污染地域住民における悪性腫瘍の罹患率のデ 一タは限られており, 発がんのリスクについて明確な結 論を出すのは困難である, と考えられる。

\section{結語}

$\mathrm{Cd}$ による腎障害は, 低分子量蛋白尿, 腎性糖尿, 全般 性アミノ酸尿, 尿細管における尿酸およびリン酸の再吸 収率の低下などを主徴とする近位尿細管障害である。こ のうち, 低分子量蛋白尿は, Cdによる健康影響のうちで 最も早期に出現するものの一つであると考えられてい 
(A)

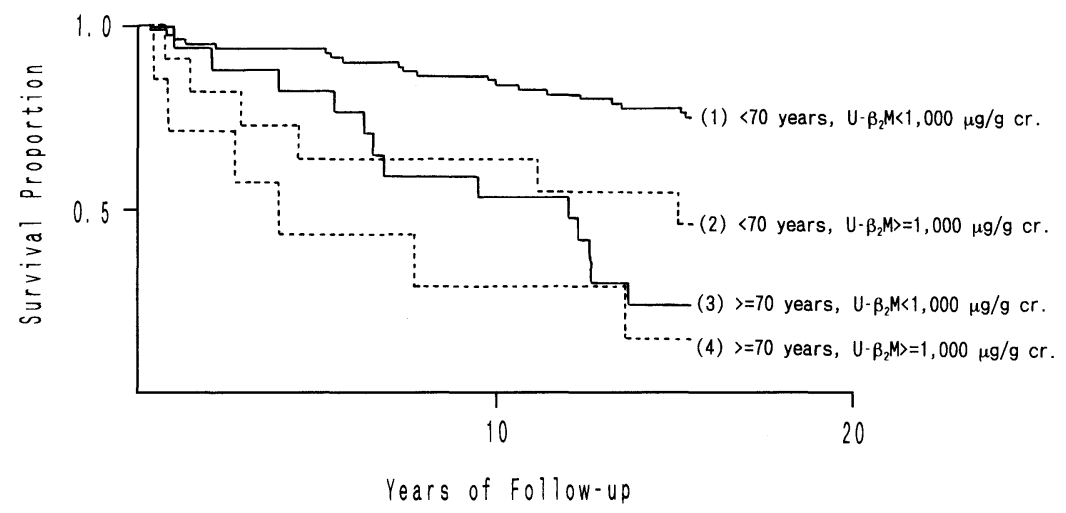

(B)

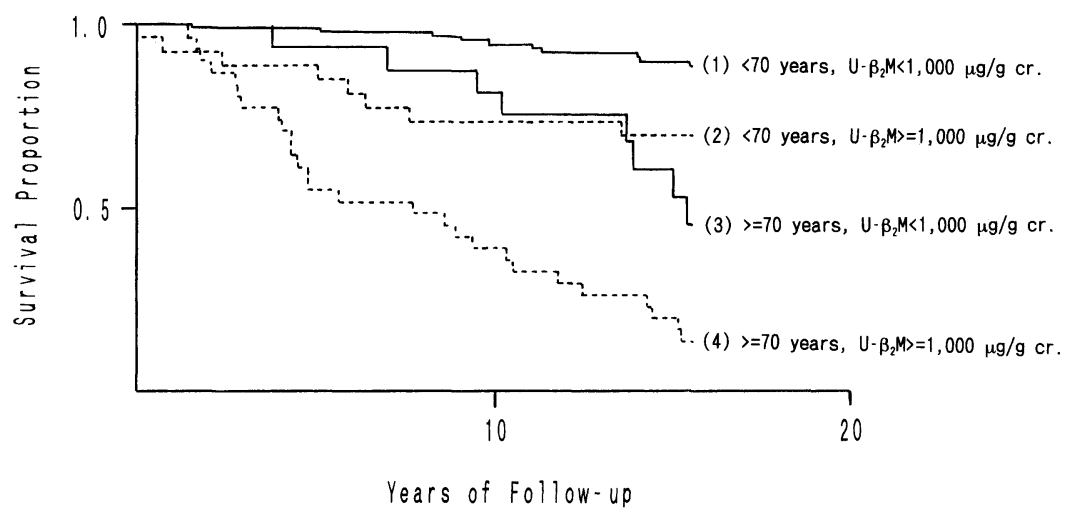

Fig. 2 Survival proportions according to age and urinary $\boldsymbol{\beta}_{2}$-microglobulin concentrations $\left(\mathrm{U}-\boldsymbol{\beta}_{2} \mathrm{M}\right)$ among men (A) and women (B). P-value for the difference was 0.02 for Group (1) vs. (2) and 0.30 for Group (3) vs. (4) among men. P-value for the difference was 0.01 for Group (1) vs. (2) and 0.004 for Group (3) vs. (4) among women. cr, creatinine.

る。したがって，低分子量蛋白尿の進展を防ぐことは, より重度の健康障害を予防する上で重要である。Cd 污 染地域住民および Cd 作業労働者における追跡調查は, 低分子量蛋白尿が，多くの場合，曝露の中止後あるいは 軽減後も不可逆性・進行性であることを明らかにした。 $\mathrm{Cd}$ による低分子量蛋白尿の予後が, $\mathrm{Cd}$ 曝露軽隇前の曝 露強度や体内 $\mathrm{Cd}$ 蓄積量によって影響を受ける可能性が ある。また, いくつかの調查で, $\mathrm{Cd}$ 曝露軽減後に糸球体 機能が徐々に低下する傾向が認められている。

日本の Cd 污染地域におけるコホート調查は, 尿細管 機能および糸球体機能の低下が総死亡率の上昇と強く関 連していることを明らかにした。しかし，尿中 $\beta_{2}-\mathrm{MG}$ 濃 度が $1,000 \mu \mathrm{g} / \mathrm{g} \mathrm{cr}$. 未満の人の死亡率が低いために, $\mathrm{Cd}$ 污染地域全体では, 必ずしも総死亡率は上昇しないと考 えられる。現時点では, Cd 污染地域住民における悪性腫 瘍の罹患率に関するデー夕は少なく, 発がんのリスクに ついて明確な結論を出すのは困難である。

\section{謝 辞}

一連の研究の実施に際し、ご指導・ご協力を賜りまし
た長崎大学医学部衛生学教室・齋藤寛教授, 国立水俣病 総合研究センター基䃈研究部・中野篤浩部長, 放射線影 響研究所疫学部・早田みどり副部長, 富山医科薬科大学 医学部公衆衛生学教室・加須屋実教授, ならびに共同研 究者の皆様に厚く御礼申し上げます。

\section{文献}

1) Friberg L. Health hazards in the manufacture of alkaline accumulators with special reference to chronic cadmium poisoning. Acta Medica Scand 1950; suppl 240: 1-124.

2) World Health Organization. International Programme on Chemical Safety. Environmental Health Criteria 134 Cadmium, Geneva: WHO, 1992.

3) Kjellström T. Renal effects. In: Friberg L, Elinder CG, Kjellström T, Nordberg GF, editors. Cadmium and Health: A Toxicological and Epidemiological Appraisal, Vol II, Boca Raton, FL: CRC Press, 1986: 21-109.

4) Tsuchiya K. Proteinuria of cadmium workers. J Occup Med 1976; 18: 463-466.

5) Roels H, Djubgang J, Buchet JP, Bernard A, Lauwerys R. Evolution of cadmium-induced renal dysfunction in workers 
removed from exposure. Scand $\mathrm{J}$ Work Environ Health 1982; 8: 191-200.

6) Roels HA, Lauwerys RR, Buchet JP, Bernard AM, Vos A, Oversteyns M. Health significance of cadmium induced renal dysfunction: A five year follow up. Br J Ind Med 1989; 46: 755-764.

7) Elinder CG, Edling C, Lindberg E, Kågedal B, Vesterberg O. $\beta_{2}$-microglobulinuria among workers previously exposed to cadmium: Follow-up and dose-response analyses. Am J Ind Med 1985; 8: 553-564.

8）加須屋実, 寺西秀豊, 䆶田裕子, 加藤輝隆, 青島恵子, 西条旨子, 岩田孝吉, 金井正光. イタイイタイ病患者 とその家族における尿中および血中低分子蛋白測定の 意義一尿中低分子蛋白の 10 年後の経過観察一. 環境保 健レポート 1986；52：176-180.

9) Kido T, Honda R, Tsuritani I, Yamaya H, Ishizaki M, Yamada Y, Nogawa K. Progress of renal dysfunction in inhabitants environmentally exposed to cadmium. Arch Environ Health 1988; 43: 213-217.

10) Iwata (Arisawa) K, Saito H, Moriyama M, Nakano A. Renal tubular function after reduction of environmental cadmium exposure: A ten-year follow-up. Arch Environ Health 1993; 48: 157-163.

11）劉暁潔. 長崎県対馬カドミウム土袞污染地域住民の頭 髪, 尿および血液カドミウム濃度一土壤復元前後 18 年 での比較一. 日衛誌 $1999 ; 54: 544-551$.

12）㚞健軍, 青島恵子, 加藤輝隆, 寺西秀豊, 加須屋実. 富 山県神通川流域カドミウム環境污染地域住民の尿細管 障害に関する追跡研究 第 1 報 土壌污染改良事業開 始後のカドミウム曝露の変化と尿細管障害の予後. 日 衛誌 1998；53：545-557.

13) Roels HA, Van Assche FJ, Oversteyns M, De Groof M, Lauwerys RR, Lison D. Reversibility of microproteinuria in cadmium workers with incipient tubular dysfunction after reduction of exposure. Am J Ind Med 1997; 31: 645-652.

14) Järup L, Persson B, Elinder CG. Blood cadmium as an indicator of dose in a long-term follow-up of workers previously exposed to cadmium. Scand J Work Environ Health 1997; 23: 31-36.

15) Buchet JP, Lauwerys R, Roels H, Bernard A, Bruaux P, Claeys F, Ducoffre G, De Plaen P, Staessen J, Amery A, Lijnen P, Thijs L, Rondia D, Sartor F, Remy AS, Nick L. Renal effects of cadmium body burden of the general population. Lancet 1990; 336: 699-702.

16) Hotz P, Buchet JP, Bernard A, Lison D, Lauwerys R. Renal effects of low-level environmental cadmium exposure: 5year follow-up of a subcohort from the Cadmibel Study. Lancet 1999; 354: 1508-1513.

17) Ikeda $M$, Moon C-S, Zhang Z-W, Iguchi $H$, Watanabe $T$, Iwami O, Imai Y, Shimbo S. Urinary $\alpha_{1}$-microglobulin, $\beta_{2^{-}}$ microglobulin, and retinol-binding protein levels in general populations in Japan with references to cadmium in urine, blood, and 24-hour food duplicates. Environ Res 1995; 70: 35-46.

18）原田孝司, 平井義修, 原耕平, 嘉村末男. カドミウム 環境污染地域における経過観察者の近位尿細管障害の
推移. 環境保健レポート 1988；54：127-133.

19) Kido $T$, Nogawa $K$, Ishizaki $M$, Honda $R$, Tsuritani I, Yamada Y, Nakagawa H, Nishi M. Long-term observation of serum creatinine and arterial blood $\mathrm{pH}$ in persons with cadmium-induced renal dysfunction. Arch Environ Health 1990; 45: 35-41.

20) Järup L, Persson B, Edling C, Elinder CG. Renal function impairment in workers previously exposed to cadmium. Nephron 1993; 64: 75-81.

21) Elinder CG, Kjellström T. Carcinogenic and genetic effects. In: Friberg L, Elinder CG, Kjellström T, Nordberg GF, editors. Cadmium and Health: A Toxicological and Epidemiological Appraisal, Vol II, Boca Raton, FL: CRC Press, 1986: 205-229.

22) International Agency for Research on Cancer. IARC Monographs on the Evaluation of the Carcinogenic Risk of Chemicals to Humans. Vol. 58 Beryllium, Cadmium, Mercury, and Exposures in the Glass Manufacturing Industry. Lyon: IARC, 1993.

23) Järup L, Bellander T, Hogstedt $\mathrm{C}$, Spång G. Mortality and cancer incidence in Swedish battery workers exposed to cadmium and nickel. Occup Environ Med 1998; 55: 755759.

24) Sorahan T, Lancashire RJ. Lung cancer mortality in a cohort of workers employed at a cadmium recovery plant in the United States: an analysis with detailed job histories. Occup Environ Med 1997； 54：194-201.

25）重松逸造, 箕輪真澄, 臼井竹次郎, 永井正規, 喜多村 正次, 武内重五郎, 福島匡昭. カドミウム環境污染地 域住民の死因に関する疫学調査研究. 環境保健レポー 卜（下巻） 1980；46：1-71.

26）重松逸造, 箕輪真澄, 永井正規, 大村外志隆, 竹内和 子. カドミウム環境污染地域住民の死因に関する疫学 調查研究 (補遺) 一富山県における污染程度別死亡率 の検討一. 環境保健レポート 1982；48：118-136.

27) Nakagawa H, Kawano S, Okumura Y, Fujita T, Nishi M. Mortality study of inhabitants in a cadmium-polluted area. Bull Environ Contam Toxicol 1987; 38: 553-560.

28) Morgenstern H. Ecologic studies. In: Rothman KJ, Greenland S, editors. Modern Epidemiology, Second Edition. Philadelphia, PA: Lippincott-Raven, 1998, 459-480.

29) Iwata (Arisawa) K, Saito H, Nakano A. Association between cadmium-induced renal dysfunction and mortality: Further evidence. Tohoku J Exp Med 1991; 164: 319-330.

30) Iwata (Arisawa) K, Saito H, Moriyama M, Nakano A. Follow up study of renal tubular dysfunction and mortality in residents of an area polluted with cadmium. Br J Ind Med 1992; 49: 736-737.

31) Nishijo M, Nakagawa H, Morikawa Y, Tabata M, Senma M, Kitagawa Y, Kawano S, Ishizaki M, Sugita N, Nishi M, Kido T, Nogawa K. Prognostic factors of renal dysfunction induced by environmental cadmium pollution. Environ Res 1994; 64: 112-121.

32) Nishijo $M$, Nakagawa $H$, Morikawa $M$, Tabata $M$, Miura $T$, Yoshita K, Higashiguchi K, Seto T, Kido T, Nogawa K, Mizukoshi K, Nishi M. Relationship between urinary cad- 
mium and mortality among inhabitants living in a cadmium polluted area in Japan. Toxicol Lett 1999; 108: 321-327.

33) Lauwerys R, De Wals P. Environmental pollution by cadmium and mortality from renal diseases. Lancet 1981 ; $\mathrm{i}$ : 383.

34) Lauwerys R, Roels H, Bernard A, Buchet JP. Renal response to cadmium in a population living in a nonferrous smelter area in Belgium. Int Arch Occup Environ Health 1980; 45: 271-274.

35) Inskip H, Beral V, McDowall M. Mortality of Shipham residents: 40-year follow-up. Lancet 1982; i: 896-899.

36) Elliott P, Arnold R, Cockings S, Eaton N, Järup L, Jones J, Quinn M, Rosato M, Thornton I, Toledano M, Tristan E, Wakefield J. Risk of mortality, cancer incidence, and stroke in a population potentially exposed to cadmium. Occup Environ Med 2000; 57: 94-97.

37) Shimbo S, Zhang Z-W, Moon C-S, Watanabe T, Nakatsuka
H, Matsuda-Inoguchi N, Higashikawa K, Ikeda M. Correlation between urine and blood concentrations, and dietary intake of cadmium and lead among women in the general population of Japan. Int Arch Occup Environ Health 2000; 73: 163-170.

38) Arisawa K, Nakano A, Saito H, Liu X-J, Yokoo M, Soda M, Koba T, Takahashi T, Kinoshita K. Mortality and cancer incidence among a population previously exposed to environmental cadmium. Int Arch Occup Environ Health 2001; 74: 255-262.

39) Ellis KJ, Yuen K, Yasumura S, Cohn SH. Dose-response analysis of cadmium in man: Body burden vs kidney dysfunction. Environ Res 1984; 33: 216-226.

40) Saito H, Iwata (Arisawa) K, Moriyama M. Mortality rate among cadmium-exposed inhabitants was significantly higher than the entire Japanese population (Letter). Arch Environ Health 1996; 51: 471-473. 